\title{
The Effect Of Giving Family's Psychososial Stimulation On Social Development Of Children With Autism Spectrum Disorder (ASD) At ADIP Center Therapy Sumber Bendo Kediri Regency
}

\author{
Luluk Susiloningtyas*, Nurin Fauziyah, Ratih Kusuma Wardhani \\ STIKES Pamenang Kediri, Indonesia \\ *luluksusiloningtyas@gmail.com
}

\begin{abstract}
Developmental delays in children with Autism can be more severe if therapy is not done. The social development of ASD children can be improved through giving psychosocial stimulation. Psychosocial stimulation can be done by therapists, mothers and other family members. Psychosocial stimulation served as a beneficial reinforcer for child development. Good psychosocial stimulation has a positive impact on the social development particularly for children with ASD.

These study used a Quasi Experiment with Non-equivalent Control Group Design. The study was conducted in July - September 2020 at the Adip Center Therapy Sumber Bendo Kediri Regency. The sampling technique was total sampling. The sample of this research is families who have children with Autism Spectrum Disorder (ASD) in the Adip Center Therapy at the age of 2-10 years. It divided to the experimental group (15 children) and the control group (15 children). The independent variable is family's psychosocial stimulation, the instrument is the HOME (Home Observation for Measurement of the Environment (HOME) Inventory) instrument. The dependent variable is the Social Development of Children with Autism Spectrum Disorder (ASD), the instrument used is an observation sheet using the Vineland Maturity Scale, with an ordinal scale. Data analysis using the Mann-Whitney test and Wilcoxon test.

The research analysis of the Mann Whitney test showed a significance of Sig $(p)=0.034 . \alpha$ $=5 \%=0.05, \mathrm{p}<\alpha$ means there are differences in social development of children with Autism Spectrum Disorder (ASD) in the treatment group with the control group, it means that there is a difference after the treatment of giving psychosocial stimulation by the family. The analysis was performed using the Wilcoxon test, it was found that $\operatorname{Sig}(\mathrm{p})=$ 0.003. $\alpha=5 \%=0.05, \mathrm{p}<\alpha$, it means that there is an effect of giving psychosocial stimulation by the family on the social development of children with Autism Spectrum Disorder (ASD).
\end{abstract}

Keywords : Psychosocial Stimulation, Social Development, Children with Autism Spectrum Disorder (ASD) 


\section{STRADA Jurnal Ilmiah Kesehatan}

DOI: $10.30994 /$ sjik.v9i2.449

ISSN: 2252-3847 (print); 2614-350X (online)

Vol.9 No.2 November 2020 Page.1092-1100

\section{BACKGROUND}

Social interaction and communication with others is an important stage for children. However, some children have difficulty in the process of social development, like a child with autism. Earlier we know about the symptoms of ASD, then we can make the best interventions to help ASD children. Psychosocial stimulation can be performed by a therapist, mother and family members. Good psychosocial stimulation of children will have a positive impact on the social development of ASD children.

Based on UNESCO data in 2011, there were 35 million people with autism in the world. This means 6 out of 1000 people in the world have autism. Director of Mental Health Development of the Ministry of Health, Diah Setia said that it is estimated that 112,000 children in Indonesia have autism, at the age of 5-19 years. Assuming the autism prevalence is 1.68 per 1000 for children under 15 years, The number of children at age of 5-19 years in Indonesia reached 66,000,805 people. Based on BPS data in 2010, it is estimated that there are more than 112,000 children with autism in the age range 5-19 years (Diah, 2012).

According to the Head of the East Java Education Office Suswanto, there are 221 children with autism (Diah, 2012). Results of researcher's preliminary study at the Adib Center Therapy Sumberbendo Kediri Regency on 25 Mei 2019, based on observations of the special curriculum for children with autism conducted on 7 Autistic children, 5 children $(71,43 \%)$ known to be unable to develop good relationships with friends, be closed and do not care about the environment and 2 children $(28,57 \%)$ friendly attitude, want to play with his friends, didn't turn around when called, no eye contact, speech development is a bit stunted. ASD children get psychosocial stimulation in the moderate category (60-80\%). However, there is still a bad category of psychosocial stimulation, namely not being able to apply psychosocial stimulation properly. The task of developing Self Help Eating, Self Help Dressing, Occupation, and Communication are in the appropriate category while Self Direction, Locomotion, and Socialization are in the poor category.

Based on the results of the interview, 5 out of 7 mothers provided psychosocial stimulation, while 2 mothers did not give. Delay in child development can be caused by a lack of parental knowledge about the psychosocial stimulation that children need because in children with autism, developmental delays can be more severe if therapy is not done.

Based on the description above, the researcher is interested in conducting research with the title "The Effect of Family's Psychosocial Stimulation on Social Development of Children with Autism Spectrum Disorder (ASD) in Adip Center Therapy Sumber Bendo Kediri Regency which hopefully can improve the social development of children with Autism Spectrum Disorder (ASD).

\section{METHODS}

These study used a Quasi Experiment with Non-equivalent Control Group Design. The study was conducted in July - September 2020 at Adip Center Therapy Sumber Bendo Kediri Regency. The sampling used is total sampling. The sample of this research is families who have children with Autism Spectrum Disorder (ASD) at Adip Center Therapy at the age of 2-10 years. It divided to the experimental group (15 children) and the control group (15 children). The independent variable is family's psychosocial stimulation, the instrument used is HOME (Home Observation for Measurement of the Environment (HOME) Inventory) instrument. The dependent variable is Social Development of Children with Autism Spectrum Disorder (ASD), the instrument used is an observation sheet using the Vineland Maturity Scale, with an ordinal scale. Data analysis using the 


\section{STRADA Jurnal Ilmiah Kesehatan}

DOI: $10.30994 /$ sjik.v9i2.449

ISSN: 2252-3847 (print); 2614-350X (online)

Mann-Whitney test and Wilcoxon test.

\section{RESULTS}

Social Development of Children with Autism Spectrum Disorder (ASD) Before and After Treatment Family's Psychosocial Stimulation Adib Center, Sumber Bendo Therapy, Kediri Regency

Table 1. Ranks Using the Mann Whitney Test about Social Development of Children with Autism Spectrum Disorder (ASD) before and after being given psychosocial stimulation treatment by families at Adib Center Therapy Sumber Bendo, Kediri Regency 2020

\section{Ranks}

\begin{tabular}{|l|l|l|l|}
\hline \multicolumn{1}{|c|}{ Groups } & N & Mean Rank & Sum of rank \\
\hline Social Development of Children Treatment & 15 & 15,50 & 232,50 \\
With Autism Spectrum Disorder Control & 15 & 15.50 & 232,50 \\
(ASD) Before Treatment Total & 30 & & \\
\hline Social Development of Children Treatment & 15 & 18,57 & 278,50 \\
With Autism Spectrum Disorder Control & 15 & 12.43 & 186,50 \\
(ASD) After Treatment Total & 30 & & \\
\hline
\end{tabular}

Based on table 1. The data results for the mean rank showed that the social development ability of children with Autism Spectrum Disorder (ASD) experimental treatment and control is 18.57 , it means that the social development ability of children with Autism Spectrum Disorder (ASD) in the experimental treatment group and the control group showed a greater value when treatment of psychosocial stimulation has been given by the family.

Table 2. Statistical Test Using the Mann Whitney Test about Social Development of Children with Autism Spectrum Disorder (ASD) Before and After Treatment Family's Psychosocial Stimulation at Adib Center Therapy Sumber Bendo, Kediri Regency 2020

\section{Test Statistics ${ }^{\mathrm{b}}$}

\begin{tabular}{|l|l|l|}
\hline & $\begin{array}{l}\text { Social Development } \\
\text { Children with Autism Spectrum } \\
\text { Disorder (ASD) before treatment }\end{array}$ & $\begin{array}{l}\text { locial Development of } \\
\text { Children with Autism } \\
\text { Spectrum Disorder (ASD) } \\
\text { after treatment }\end{array}$ \\
\hline Mann-Whitney U & 112,500 & 66,500 \\
Wilcoxon W & 232,500 & 186,500 \\
$Z$ &, 000 & $-2,120$ \\
Asymp. Sig. (2-tailed) & 1,000 &, 034 \\
Exact Sig. [2*(1-tailed Sig.)] & $1,000^{\mathrm{a}}$ &, $056^{\mathrm{a}}$ \\
\hline
\end{tabular}

a. Not corrected for ties

b. Grouping Variable Kelompok 


\section{STRADA Jurnal Ilmiah Kesehatan}

DOI: $10.30994 /$ sjik.v9i2.449

ISSN: 2252-3847 (print); 2614-350X (online)

Vol.9 No.2 November 2020 Page.1092-1100

Based on table 2. The results of data analysis using the Mann Whitney test at the time after being given treatment to the experimental group and the control group, namely the results of the analysis showed that the significance of $\operatorname{Sig}(p)=0.034 . \alpha=5 \%=0.05, p<\alpha$ then Ho is rejected Ha accepted means that there is a difference between treatment group and control group after the treatment is received, it means that there is a difference after the treatment of stimulation psychosocial by family has been given.

\section{The Effect of Family's Psychosocial Stimulation on Social Development of Children with Autism Spectrum Disorder (ASD) at the Adip Center Sumber Bendo Therapy Kediri Regency}

Table 3. Results of Treatment Group Ranks Analysis Using the Wilcoxon Test about Effect of Family Psychosocial Stimulation on Social Development of Children with Autism Spectrum Disorder (ASD) at Adib Center Therapy Sumber Bendo, Kediri Regency 2020

\section{Wilcoxon Signed Rank Test Ranks}

\begin{tabular}{|l|l|l|c|}
\hline & $\mathbf{N}$ & Mean Rank & Sum of Rank \\
\hline Social Development of Children Negatif Ranks & $0^{\mathbf{a}}$ &, 00 &, 00 \\
With Autism Spectrum Disorder Positive Ranks & $9^{\mathbf{b}}$ & 5,00 & 45,00 \\
(ASD) After Treatment Ties & $6^{\mathbf{c}}$ & & \\
Social Development of Children Total & 15 & & \\
With Autism Spectrum Disorder & & & \\
(ASD) Before Treatment & & & \\
\hline
\end{tabular}

a. Social development of ASD children after treatment $<$ Social development of ASD children before treatment

b. Social development of ASD children after treatment > Social development of ASD children before treatment

c. Social development of ASD children after treatment = Social development of ASD children before treatment

Table 4. Results of Statistical Test on Treatment Group Using the Wilcoxon Test about Effect of Family's Psychosocial Stimulation on Social Development of Children with Autism Spectrum Disorder (ASD) at Adib Center Therapy Sumber Bendo, Kediri Regency 2020

\section{Test Statistics b}

\begin{tabular}{|l|lr|}
\hline & $\begin{array}{l}\text { Social Development of Children with Autism } \\
\text { Spectrum Disorder (ASD) after treatment- } \\
\text { Social Development of Children With Autism } \\
\text { Spectrum Disorder (ASD) Before Treatment }\end{array}$ \\
\hline Z & & $-3,000^{\mathbf{a}}$ \\
Asymp. Sig. (2-tailed) & &, 003 \\
\hline
\end{tabular}

a. Based on negative ranks

b. Wicoxon Signed Ranks Test 


\section{STRADA Jurnal Ilmiah Kesehatan}

DOI: $10.30994 /$ sjik.v9i2.449

ISSN: 2252-3847 (print); 2614-350X (online)

Vol.9 No.2 November 2020 Page.1092-1100

Table 5. Results of Control Group Ranks Analysis Using the Wilcoxon Test Effect of Family's Psychosocial Stimulation on Social Development of Children with Autism Spectrum Disorder (ASD) at Adib Center Sumber Bendo Therapy, Kediri Regency 2020

Wilcoxon Signed Rank Test Ranks

\begin{tabular}{|l|l|l|c|}
\hline & N & Mean Rank & Sum of Rank \\
\hline Social Development of Children Negatif Ranks & $0^{\mathbf{a}}$ &, 00 &, 00 \\
With Autism Spectrum Disorder Positive Ranks & $1^{\mathbf{b}}$ & 1,00 & 1,00 \\
(ASD) After Treatment Ties & $14^{\mathbf{c}}$ & & \\
Social Development of Children Total & 15 & & \\
With Autism Spectrum Disorder & & & \\
(ASD) Before Treatment & & & \\
\hline
\end{tabular}

a. Social development of ASD children after treatment < Social development of ASD children before treatment

b. Social development of ASD children after treatment> Social development of ASD children before treatment

c. Social development of ASD children after treatment $=$ Social development of ASD children before treatment

Table 6. Results of the Statistical Test on Control Group Using the Wilcoxon Test Effect of Family's Psychosocial Stimulation on Social Development of Children with Autism Spectrum Disorder (ASD) at the Adib Center Sumber Bendo Therapy, Kediri Regency 2020

\section{Test Statistics ${ }^{\mathrm{b}}$}

\begin{tabular}{|l|lr|}
\hline & $\begin{array}{l}\text { Perkembangan Sosial Anak Autism Spectrum Disorder } \\
\text { (ASD) after treatment- } \\
\text { Social Development of Children With Autism Spectrum } \\
\text { Disorder (ASD) Before Treatment }\end{array}$ \\
\hline $\mathrm{Z}$ & & $-1,000^{\mathrm{a}}$ \\
Asymp. Sig. (2-tailed) & &, 317 \\
\hline
\end{tabular}

a. Based on negative ranks

b. Wicoxon Signed Ranks Test

Based on Table 6, the results of the statistical test data analysis of the treatment group using the Wilcoxon test showed that the significance of Sig $(p)=0.003 . \alpha=5 \%=0.05, p$ $<\alpha$ then Ho is rejected and $\mathrm{Ha}$ is accepted, means that there is an effect of stimulation on the social development of children with Autism Spectrum Disorder (ASD) with a strong effect. 15 children with Autism Spectrum Disorder (ASD) whose social development increased (positive), 9 children $(60 \%), 6$ children $(40 \%)$ continued social development $(40 \%)$ and none decreased $(0 \%)$. 


\section{STRADA Jurnal Ilmiah Kesehatan}

DOI: $10.30994 /$ sjik.v9i2.449

ISSN: 2252-3847 (print); 2614-350X (online)

Vol.9 No.2 November 2020 Page.1092-1100

Based on the results of research, it can be seen that there is an effect of providing psychosocial stimulation by the family on the social development of children with Autism Spectrum Disorder (ASD) with a strong effect.

\section{DISCUSSION}

\section{Social Development of Children With Autism Spectrum Disorder (ASD) Before and} After being given treatment Family's Psychosocial Stimulation

The results of observations at the Adip Center Therapy Sumber Bendo Kediri Regency which has been going on for 6 meetings. This study consisted of 30 subjects at aged 2-10 years, it divided to 15 respondents in the treatment group and 15 respondents in the control group. The indicators from the research were included in the observation sheet using the Vineland Social Maturity Scale assessment. The social development abilities studied include SHG (Self Help General), SHE (Self Help Eating), SHD (Self Help Dressing), SD (Self Direction), O (Occupation), C (Communication) L (Locomotion), S (Socialization). Psychosocial stimulation is carried out using HOME (Home Observation Measurement Environment Inventory). The results showed that there were differences before and after giving psychosocial stimulation by the family, So it can be concluded that the provision of psychosocial stimulation treatment is effective in improving the social development abilities of children with Autism Spectrum Disorder (ASD) because there are changing before and after treatment family's psychosocial stimulation.

It complianced with the data analysis which showed that there is a significant difference between the mean rank and the sum of ranks, the value of the experimental group is higher.

According to L. Thorndike, the law of exercise stated that the relationship between stimulus and response will be strong if it is used frequently. This law stated that the relationship between stimulus and response will be weak if there is no training. The results of the research that have been obtained indicate that after being given intervention, On average, the subjects' experience have an increase in their social development skills compared to their social development abilities before being given the intervention. The analysis results have been described above, the possibility still does not show a match between the results of the study and the theoretical basis used to explain the process of providing psychosocial stimulation. Increasing the ability of social development in children with Autism Spectrum Disorder (ASD) requires treatment (therapy) that is often carried out not only 6 meetings but continuously so that the development of children with Autism Spectrum Disorder (ASD) can be more visible.

The results of observations stated it is also known that the results of development in terms of independence tasks are mostly suitable, it can be seen from the aspect of Self Help Dressing (SHD) being able to dress themselves, Self Help Eating (SHE) in terms of eating well, Occupation $(\mathrm{O})$ children can take the initiative To play alone, Socialization $(\mathrm{S})$ is able to work together with peers. The results of the observations are in accordance with Grandin's (1995) statement that ASD children are specialized in storing information, namely visually. So if ASD children see their mother's daily activities, they will remember how to use brooms, mops, and cut paper because the visual power of ASD children is so strong (Peeters 2004). However, ASD children's activities still need supervision because they have a very strong memory and they like risky objects such as scissors or knives. This is because if ASD children like these objects they do not want to be replaced with other objects. One of the characteristics of ASD children is the presence of a unique pattern of behavior, namely attachment to certain objects (Budhiman 2000).

However, the results of this study indicate that not all ASD children develop in 


\section{STRADA Jurnal Ilmiah Kesehatan}

DOI: $10.30994 /$ sjik.v9i2.449

ISSN: 2252-3847 (print); 2614-350X (online)

Vol.9 No.2 November 2020 Page.1092-1100

developmentally deficient criteria. The development can be seen based on the Loccomotion (L) aspect, the child has not dared to play freely outside the home, aspects of Self Direction (SD) are shown by not being able to use their own money to transact with other people. According to Puspita (2004) referred to in Suryana (2004) stated that generally there is a reluctance for ASD children to interact actively with other people, because the child feels often disturbed by the presence of other people around him, can not play with peers, prefer to be alone and others. This suggested that there may be other factors that affect the social development of children with Autism Spectrum Disorder (ASD). According to Taufik (2007) Other factors are possible due to internal factors, namely differences in race or ethnicity, family, sex, genetics, chromosomal abnormalities, prenatal factors, childbirth and postpartum factors. Another factor may be also due to the nutrition that children get, because nutritious food present an important role in children's development. Besides that, it also affects the social development of children. There are factors of social experience and learning experience. This is reinforced by Hurlock's (1978) statement that children's attitudes towards others are influenced by years of social experiences and learning experiences.

Based on the research results, most of the development of children with Autism Spectrum Disorder (ASD) is influenced by the characteristics of their parents, one of which is the provision of psychosocial stimulation. Therefore, parents should provide appropriate stimulation according to the needs of their children so that children are more comfortable and can improve their development properly. Thus it is expected that all parents always provide regular care in providing care, especially good psychosocial stimulation for their children. This is so that each child can maximize their growth and development.

\section{The Effect of Family's Psychosocial Stimulation on the Social Development of Children with Autism Spectrum Disorder (ASD)}

Based on the research's results, it can be seen that the treatment group in the experimental group using Wilcoxon test, showed the significance of Sig $(p)=0.003$. $\alpha=$ $5 \%=0.05, \mathrm{p}<\alpha$, it means that there is an effect of stimulation on the social development of children with Autism Spectrum Disorder (ASD) with a strong effect.

The stimulation provided by the family is an important factor in the growth and development of children, especially children's social development, Early stimulation, by providing a conducive environment for learning, reward or reasonable punishment is what can foster strong motivation in children's development later in life. In the process of socializing with their environment, children need peers who are also very influential on children's social development. In addition to school, love and affection, the quality of children's interactions with their parents can affect the child's development process (Soetjtiningsih, 2012).

This is in accordance with the research of Ernawati, Monalisa, Ika Heryanti (2015) which stated that there is a significant relationship between family support and social interaction in autistic children with ( $p$ value $0.049<0.05$ ) which stated that if family support is good, then the child's social interaction autism is also good.

Increasing in social development of children with Autism Spectrum Disorder (ASD) can also be influenced by several factors. Factors that influence children's social development include support from a good environment that will provide positive things for children's development, the older the child, the less time children spend with adults. At the same time, their interest in playmates who are their same age increases and the pleasure they get from this association is getting stronger. The results of this study were also 


\section{STRADA Jurnal Ilmiah Kesehatan}

DOI: $10.30994 /$ sjik.v9i2.449

ISSN: 2252-3847 (print); 2614-350X (online)

Vol.9 No.2 November 2020 Page.1092-1100

supported by research by Yuli Setyaningrum, Anny R.M., Ina Zulia A. (2018) which stated that the results of the study were very significant, (p.value: 0,$000 ; \alpha: 0,05 ; \mathrm{r}: 0,958$ ) and stated that there was a significant relationship between social support and the ability to socialize children with autism at the Pondok Pesantren ABK Al Achsaniyyah Kudus.

The results of this study are also fit to the research of Wiwik Setyaningsih (2018) which stated that there is a relationship between parenting and social development of children with autism ( $p$-value $0.002<0.05$ ), The correlation coefficient is positive at 0.459 and has a positive value, which means that the relationship is unidirectional, so that the better the parenting style for children, the more they will improve the social development of children with autism.

Based on the results of the research, it can be used as input for families, especially parents, to be able to create an atmosphere of comfort and tranquility for children with Autism Spectrum Disorder (ASD) and be excited to improve their learning abilities. Psychosocial stimulation that given to children must be in accordance with the child's developmental needs. Appropiate psychosocial stimulation is able to give to the children the opportunity that they are part of the people in their environment so that the child can develop optimally.

Therefore, Psychosocial Stimulation in children should be done lovingly and without coercion so as to create a pleasant environment for children. Families must spend the best possible time for their children to be supervised, give attention and affection, and communicate so that the family is able to understand the development needs of their children.

\section{CONCLUSION}

Giving psychosocial stimulation by families with the HOME (Home Observation Measurement Environment Inventory) method to be used as an alternative to psychosocial stimulation to improve social development in children with Autism Spectrum Disorder (ASD). For suggestion, there should be further research regarding the provision of psychosocial stimulation by families on the social development of children with Autism Spectrum Disorder (ASD) and other factors that affect the social development of children with Autism Spectrum Disorder (ASD).

\section{ACKNOWLEDGEMENT}

The authors wish to thanks to Direktorat Riset dan Pengabdian Masyarakat (DRPM) Kemenristekdikti 2020 with research contact No: 131 / SP2H / LT-MONO / LL7 / 2020. The authors wish to thanks to Adip Center Therapy Sumber Bendo Kediri Regency.

\section{REFERENCES}

Atik Badi'ah. (2019). Pengaruh Stimulasi Skill Play Terhadap Perkembangan Motorik Kasar Anak Autism. Politeknik Kesehatan Kemenkes Yogyakarta Jurusan . $\begin{array}{llllll}\text { Vol } & 11 & \text { No. } & 1 & \text { Juni } & 2019 .\end{array}$ http://ejurnal.stikeseub.ac.id/index.php/jkeb/article/view/331

Adriana, D. (2011). Tumbuh Kembang dan Terapi Bermain Pada Anak. Jakarta : Salemba Medika

Anfamedhiarifda. (2006). Pengaruh Stimulasi Psikososial di Kelompok Bermain terhadap Karakter Anak Usia 2-4 tahun [skripsi]. Bogor : Fakultas Pertanian, Institut Pertanian Bogor.

[Anonym]. 2007. Soul of Hadi. http://www.autism.org 


\section{STRADA Jurnal Ilmiah Kesehatan}

DOI: $10.30994 /$ sjik.v9i2.449

ISSN: 2252-3847 (print); 2614-350X (online)

Vol.9 No.2 November 2020 Page.1092-1100

Cumo, Christoper. (2019). What You Need Know About Autism. Santa Barbara California : ABC-CLIO, L

Ernawati, Monalisa, Ika Heryanti. (2015). Hubungan Dukungan Keluarga Dengan Interaksi Sosial Pada Anak Autis Di SLB Prof. Dr. Sri SoeDewi Masjhun Sofwan SH Jambi Tahun 2015. Jurnal Poltekkes Jambi, Vol VIII Nomor 3 Edisi Oktober, ISSN : 2085 - 1677

Fida dan Maya (2012). Pengantar Ilmu Kesehatan Anak. Jogjakarta. D - Medika

Huzaemah. (2010). Kenali Autisme Sejak Dini. Jakarta : Pustaka Populer Obor

Huzaimah (2010). Penyebab terjadinya autis. www. Penyebab autis.com

Hasdianah, DR. (2013). Autis Pada Anak Pencegahan, Perawatan, dan Pengobatan. Yogyakarta : Nuha Medika

Hasdianah. (2013). Autis pada anak. Yogyakarta : Nuha Medika

Judarwanto W. (2007). Pencegahan Autis pada anak. http://www.puterakembara.co.id

Masra F. 2007. Autisme: Gangguan Perkembangan Anak.www.autis.com

Notoatmodjo, S. (2005). Metodologi Penenelitian Kesehatan. Jakarta : PT. Rineka Cipta

Nursalam. (2008). Konsep dan Penerapan Metodologi Penelitian Ilmu Keperawatan. Jakarta : Salemba Medika

Priyatna, Adi. (2010). Amazing Autism. Indonesia : Elex Media Computindo.

Rokhimah, Rina \& Darmawanti Ira. (2013). Pengaruh Permaianan Lasy Terhadap Peningkatan Kosentrasi Pada Anak Autis. Jurnal Psikologi Teori \& Terapan, Vol. 4, No.11,48 -55.

Safaria, T. (2005). Interpersonal Intellegence : Metode Pengembangan Kecerdasan Interpersonal Anak. Yogyakarta : Amara Books

Santoso Hargio. (2012). Cara Memahami dan Mendidik Anak Berkebutuhan Khusus. Yogyakarta: Gosyen Publishing

Veskarisyanti, G. A. (2008). 12 Terapi Autis Paling Efektif \& Hemat: Untuk Autisme, Hiperaktif \& Retardasi Mental. Yogyakarta: Pustaka Anggrek.

Wieke Oktaviani. (2008). Riwayat Autisme, stimulasi Psikososial dan Hubungannya dengan Perkembangan Sosial Anak Dengan Gangguan Autism Spectrum Disorder (ASD) Di Banten. Program Studi Gizi Masyarakat dan Sumber Daya Keluarga. [skripsi]. Bogor: Fakultas Pertanian, Institut Pertanian https://adoc.pub/riwayatautisme-stimulasi-psikososial-dan-hubungannya-dengan.html

Wiwik Setyaningsih. (2015). Hubungan Pola Asuh Orang Tua dengan Perkembangan Sosial Anak Autisme di SLB Harmoni Surakarta. Jurnal Kesehatan Politeknik Kesehatan Tanjung ISSN Online 2548-5695 ISSN Print 2086-7751, Vol 6, No 2 https://ejurnal.poltekkes-tjk.ac.id/index.php/JK/article/view/92/83

Yatim, F. (2007). Autisme: Suatu Gangguan Jiwa Pada Anak-anak. Jakarta : Pustaka Populer Obor.

Yuli Setyaningrum, Anny R.M., Ina Zulia A. (2018). Hubungan Dukungan Sosial Dengan Kemampuan Sosialisasi Anak Autisme Di Yayasan Pondok Pesantren ABK Al-Achsaniyyah Kudus Tahun 2017. Jurnal Ilmu Keperawatan dan Kebidanan $\begin{array}{lllll}\text { Vol.9 No.1 (2018) } & \text { 44-50. }\end{array}$ https://www.researchgate.net/publication/323147673 